\title{
Literacies In/For Action: Prefigurative Pedagogies and Collective Knowledge Projects
}

\section{Gerald Campano - University of Pennsylvania}

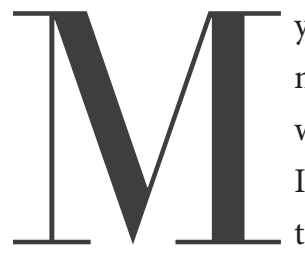

y copy of the first issue of Literacy in Composition Studies is thoroughly marked up. It engages issues, questions, and even anxieties I have carried with me over my roughly twenty years as a teacher and literacy researcher. In an effort to continue the conversation I am going to take up two themes that thread through many of the initial articles and their responses. The

first theme regards the conceptual tropes we use to describe our work. The second relates to transformative potential and, equally as important, limitations of scholarship that is directed to providing access and opportunity to historically disenfranchised students and communities. This interest in equity is something I believe many share across the areas of Literacy Education and Composition and Rhetoric.

In his opening essay, Bruce Horner argues for a shift from spatial to temporal metaphors in the conceptualization of literacies. Spatial metaphors risk essentializing literacy practices-exoticizing or romanticizing them-and even reproducing the very autonomous ideologies the field has worked so hard to deconstruct. A methodological focus on temporality may help researchers work through some of these contradictions (Horner 4-5). In a similar vein, many of the subsequent authors invoke the terms "purpose," "labor," “intentionality," "process," “circulation," “work," and "movement," a historicizing direction that I for the most part endorse, and which seems to be in line with the empirical realities of global migrations and transnationalism. My qualification is because phrases like "emergent dynamism" shade into the discourse of neoliberal incursions into education, which valorize innovation, as there will always be new literacies, and literate identities, to market. A renewed emphasis on temporality may also exist in tension with another acknowledgement made by several of the contributors: that there is often, following Pierre Bourdieu, significant social inertia and reproduction in the field of education, even as we work within and against the system to try to expand what constitutes academic knowledge and practice. This tension can induce some self-reflection and soul searching for scholars who try to balance an analytical disposition, the pressures to generate new terms and ideas for the academic market, and the desire to make a difference in students' lives.

My own contribution engages these themes from the vantage point of having taught and conducted research with elementary school students and their families in predominantly under- 
resourced but robustly diverse contexts of learning. I briefly sketch two examples of what might be thought of as literacies in/for action, one from my dissertation work as a fifth-grade teacher researcher and another from my current project at a multilingual and multiethnic faith-based organization. My interpretation of these examples is informed by much of the work cited thus far in the conversation, but also by two other intellectual traditions which sponsored my own development as a literacy scholar: the practitioner research movement (e.g. Cochran-Smith and Lytle) and realist theories of experience and identity (e.g. Alcoff; Mohanty; Moya). Both traditions, in their own ways and disciplinary contexts, share a commitment to democratizing knowledge, raising questions about who is positioned as knowing in teaching and research and "taking seriously" (Mohanty 230) the epistemic privilege of subordinated social locations. These theoretical and methodological orientations inform how I navigate the themes and contradictions described in the opening issue of Literacy in Composition Studies.

As a teacher researcher in California, I worked in a neighborhood that spatially had remained one of the most economically segregated in the state, yet from a temporal standpoint, was dynamic in the language and literacy practices of its youth. This dynamism was reflected in a performance arts and literacy group my fifth graders called Dancing Across Borders (DAB), formed under the guidance of Angelica, a talented instructor who was part of a program for college students from migrant backgrounds who were interested in becoming teachers (Campano 90-103). The troupe recited spoken-word poetry, danced, shared their essays, and scripted and produced plays, including one about the braided history of Filipino and Mexican farmworkers in California's Central Valley. They even took their work on tour, performing for community-based organizations, local colleges, and a Stanford University course on Chicana Literature and Cultural Criticism. At one point I was invited to conduct a professional development workshop on classroom "management" for our district, and I recruited the DAB troupe to help. They decided to write about times of miscommunication between teachers and students, which evolved into a performance art piece entitled "What the Teacher Didn't Know," a fictional account informed by their own experiences and observations. The performance staged a bustling but tense classroom and a series of power struggles between the teacher, Mr. Sid, whom the children told me was modeled after Dickens's Mr. M'Choakumchild, and individual students. After each conflict, all the actors would freeze, and then the character reprimanded by Mr. Sid recited a soliloquy - a device the class embraced from our studies of Shakespeare-about "what the teacher didn't know." The performance was both humorous and poignant, as each soliloquy raised to critical consciousness inequities related to class, culture, and language difference that often lurk beneath the surface of classroom "management" struggles. In an act of empathy and generosity, the DAB troupe reserved the final soliloquy for Mr. Sid himself who, a one-dimensional villain throughout most of the performance, became humanized as he recounted the challenges of being a teacher in a severely under-resourced school district.

The writings of the Dancing Across Borders troupe exemplified many of the characteristics of the academic "essayist" tradition, meeting and surpassing any codified fifth-grade standard. The 
plays may also be considered hybrid texts, written in several languages, including English, Spanish and Illocano, various literary, comic, and conversational registers and, resonant with the current valorization of multiple modalities, dramatically conveyed through gesture and voice. A New Literacy Studies methodological lens (e.g., Barton and Hamilton; Street) also helped me understand the practices of Angelica and my students contextually beyond the fact that their texts and performances were multilingual and genre $b(1)$ ending. The creative labor of DAB enacted alternative ways of knowing and being, a phrase that calls for specification. Following Allan Luke's caveat on the need to challenge the assumption "that there are generalizable and universal ways of teaching writing" (71), what I found pedagogically interesting about DAB was how their composing processes transgressed the ideology of individual authorship that underpins so much of schooling and the high-stakes testing paradigm in the United States.

It was only after some time spent with Angelica and the students that I realized their creative labor was informed by El Teatro Campesino, an activist and artistic legacy that grew out of the local intellectual soil of the migrant labor camps in the area. Similar to El Teatro, the plays of DAB were collectively produced living texts that were revised and improvised in the process of performance, sometimes in response to audience feedback (Broyles-González). Often there was no single author to their plays; all the students would contribute to the collaborative process of authoring in unique and, ideally, complementary ways. Many children who were positioned as struggling in the mandated, standardized literacy curriculum of the school blossomed in DAB, which cultivated an ethos of interdependence rather than competition and the individuation of learners as conforming to or deviating from a norm.

In "What the Teacher Didn't Know" the students also expressed some of their own critiques of schooling and employed political theatre as a vehicle to educate educators. Their insights were in part derived from inquiry into their own minoritized experiences and identities, what realist theorists conceptualize as epistemic privilege (Moya 479). The students wanted their audiences to take seriously their claims about schooling, particularly the ways in which the institution can exclude and perpetuate inequality. The work of Angelica and the students prompted me to conjoin the word prefigurative, which circulates in many activist communities, with pedagogy. Through the prefigurative pedagogy of teatro the students were at once critiquing the more dehumanizing aspects of their schooling while simultaneously prefiguring and enacting an alternative literacy curriculum: one that fosters cooperation and celebrates human variance, including the multifarious literate and intercultural resources which fertilized their creative and intellectual imaginations.

The second example comes from my current research in a multilingual and multiethnic faithbased organization, St. Cabrini (a pseudonym) that advocates for its immigrant, migrant, and refugee communities. St. Cabrini has regular mass in four different languages and recently opened a community center on its premises that serves the larger neighborhood. I became involved with St. Cabrini three years ago when I attended a "know your rights" workshop about undocumented status sponsored by a local grassroots interfaith immigrant rights organization. One of my 
interests as a literacy scholar is in how various advocacy discourses, emanating from the diverse and overlapping social locations of community members and activists, interanimate one another. These discourses, evident in both texts, parish meetings, and public events, include the following: a religious one of universal humanity (e.g., "We are all God's children" and "We are all citizens of Heaven"); the testimonial tradition, where individuals narrate injustices, such as the separation from family members; the legal terminology of attorneys who volunteer their expertise; academic analysis; and activist linguistic interventions into commonsense media language that scapegoats groups. What my research team and I are learning is that the various discourses are rhetorically and epistemically stronger together than they are on their own: the sum is greater than the individual parts. The discourses exist in a synergistic relationship with one another, resonating with Steve Parks's call for "new collaborative literacy strategies designed to foster a greater collective good" (43) and what we have termed elsewhere as coalitional literacy practices (Campano, Ghiso, Gee, and Pantoja 315). What binds the various discourses together is a larger vision of social justice, not just for immigrants but for all humans.

With these two examples in mind, I'd like to return to some of the anxieties provoked in me by the first issue of Literacy in Composition, if only to raise additional questions and conceptual orientations for research and teaching. One metaphor used by Mary Soliday that might help reconcile the spatial with the temporal dimensions of literacy is that of the "bridge," as in bridging "everyday" with "academic" literacy practices (49). A bridge certainly suggests movement and the possibility of "permeability" (49) between boundaries. It also potentially re-inscribes the two locations on either side of the bridge as relatively autonomous, and too often the movement is uni-directional: educators build off students' everyday literacy practices in order for them to gain access to academic literacies, which are assumed to be an unqualified good, as the "literacy myth" (Graff) reminds us. Many students may not have the resources to make that journey but others may not be that interested either, especially if it entails compromising their cultural identities or values.

The bridge metaphor feels like it has explanatory power in my own family story. There was some intergenerational crossing between the literate world of my grandfather, a multilingual migrant from a subaltern community in the Mindanao region of the Philippines, and my own monolingual life as a teacher and scholar of literacy here in the United States. My schooling growing up was assimilationist and my family, perhaps not unlike many immigrant families, maintained a fetishistic belief in the transformative power of education as a vehicle for upward mobility and personal growth. I didn't have teachers who explicitly challenged the ideology of the autonomous model of literacy or raised issues of coloniality in education. Through my own teaching and research over the years with communities like DAB and St. Cabrini, I have gravitated toward the borderland, borderthinking, "world"-travelling metaphors of scholars such as Gloria Anzaldúa, Walter Mignolo, and María Lugones over bridges because of how they unsettle hierarchical binaries.

In this spirit María Paula Ghiso and I (Campano and Ghiso) have argued for the pedagogical and theoretical ideal of viewing all students as cosmopolitan intellectuals who have the capacities to 
draw from a range of cultural resources and legacies in the literacy curriculum in order to critically engage the world. We specifically advocate for a cosmopolitanism from below (Anderson); it is not just that schools ought to make students global citizens, but rather they may acknowledge how many students in our $21^{\text {st }}$ century communities already are cosmopolitan intellectuals by virtue of their diasporic identities, firsthand experiences negotiating the underside of neoliberalism, and exposure to diverse literary and activist legacies. The purposes of a literacy curriculum might in part be to nurture their critical cosmopolitan impulses and create an environment where all members of a learning community learn from one another's epistemic privilege.

I don't believe an orientation toward border-thinking and cosmopolitanism will automatically transcend the dilemmas presented by the symposium contributors, who have astutely invoked Bourdieu to remind us of the durability of social dispositions, including the essayist text, and the difficulty of change. I know that I still have deep professional and personal investments in the possibility of literacy as transformation, and that efforts to think about literacies more inclusively in teaching may invariably engender new hierarchies and exclusions. It is probably a healthy anxiety for our field to acknowledge that there may be a little Mr. Sid/ Mr. M'Choakumchild in all of us due to our affiliations with institutions of power and social reproduction and the fact we traffic in some of the very autonomous ideologies we critique. I do believe we might more explicitly address knowledge questions in literacy and composition, however framed, and put key terms such as epistemic privilege and historically subordinated knowledge in more circulation-concepts I expected several authors to take up given the direction of their pieces but from which they ultimately shied away.

The knowledge questions are important because a thoughtful redistribution of intellectual authority in our collaborative research and teaching might go some way in mitigating any tendency in literacy studies to pin down and examine various new and old literacies like exotic butterfly collectors. As educators we may be less interested in how literacy practices move about in insular ecologies - an impulse which would prompt the concern of relativism brought up in the articles-and more with how the participants in our local research contexts employ various literacies to generate knowledge about our shared world. In both examples of DAB and St. Cabrini, the pedagogies were not geared toward merely demystifying and providing access to the power codes, but fundamentally changing students' and community members' relationship to them. The participants in fact created their own power codes by drawing on multiple literate resources to both navigate the social world as well as make normative claims about this world and how it might be better. For example, the children in $\mathrm{DAB}$ had something important to say regarding classroom management and the conditions for a more humane learning environment. Members of the St. Cabrini community mobilized complementary discursive resources to reveal the biopolitics of bureaucratic immigration policies that create states of exception (Agamben), what Kate Vieira shrewdly names as the link between literacy and identification, as well as how these policies and practices ought to be revised, rescinded, or resisted. We might find, for example, that our students or research participants, especially if they are from a (post)colonial context, have their own critiques related to the arbitrary nature of 
dominant and ostensibly autonomous literacy practices. They may also have important insights into how literacies, academic ones included, position some people as knowers and others, through a type of secular missionary ideology, as the benefactors of their knowledge.

It may be that understanding individuals and communities' literacies is the first step to learning from their own insights and inquiries, but my inclination is that the two go hand in hand. In her elegantly reasoned and incisive book Epistemic Injustice: Power and the Ethics of Knowing, the philosopher Miranda Fricker reminds us of how the credibility of an individual's knowledge claims may be arbitrarily deflated because of systematic identity prejudice, what she labels a testimonial injustice, and argues for the intellectual and ethical virtue of being a responsible hearer (27-28). This virtue concerning the epistemic value of relationships is one that scholars in the fields of literacy and composition studies are uniquely positioned to cultivate in our teaching and research methodologies, building on our own respective intellectual histories of working across social and cultural boundaries. By taking seriously others' knowledge as conveyed through their literacies and rhetorical traditions, we may also transfigure our own academic practices.

As an educator, I have taught first graders through doctoral students. Despite the many rewards of the profession, one of its more dispiriting aspects is when I hear from former students whose literate and intellectual identities are eventually devalued or denied in school. Even students who navigate their educational trajectories with some degree of self-determination and success often do so at considerable cost. Several months ago one of the leaders of Dancing Across Borders got in touch with me after many years. She had been waiting to contact me until she graduated from one of the institutions represented on this journal's Editorial Board (and I imagine may have been taught by at least one of our colleagues, a reminder that, at the very least, human lives may connect our academic silos and disparate institutional contexts). The student embodies a cosmopolitan intellectual orientation by any definition: in addition to excelling in academic literacies, she knows several languages, code switches between youth vernaculars, is an artist, and has transnational activist commitments and intellectual interests. Nevertheless, her college education became protracted, and at one point she almost dropped out altogether because of personal issues related to systemic inequities, including a family health emergency compounded by a lack of medical insurance and complications related to immigration: issues not unrelated, I believe, to the links Vieira is making in her ethnographic work between literacy, the regulating power of institutional texts, and who is and is not included in the nation state.

The stories of many of my former students are a sharp reminder of my own limitations as an educator. Still, the notion that any one researcher or teacher's practice substantively intervenes into what Bourdieu might characterize as the broader field of education, which itself might be located within a larger universe of hierarchically structured fields (Bourdieu and Wacquant), can reflect a liberal bourgeoisie ideology that individuals author change through a sheer exertion of will. One of the academic practices I am trying to amplify in my own work is its collaborative dimension. If literacy practices do not have ontological stability but instead are products of human history, then 
the hope is that those naturalized literacies that have been employed to dehumanize and disqualify might be challenged through collective effort. It would be important for these efforts to be guided by a vision of social justice informed by the epistemic privilege of those whose perspectives have been devalued due to systematic identity prejudice. Groups such as El Teatro Campesino and members of St. Cabrini have taught me that change best occurs through collective knowledge projects, whether situated in communities of inquiry with our students or teachers, alongside our partners in their own sites of activism, or part of continuing conversations in journals such Literacy in Composition Studies, where scholars from diverse backgrounds are dancing across disciplinary boundaries in order to think through some of the most complex and demanding educational issues of our time. 


\section{WORKS CITED}

Agamben, Giorgio. State of Exception. Chicago: U of Chicago P, 2005. Print.

Alcoff, Linda Martín. Visible Identities: Race, Gender, and the Self. Oxford: Oxford UP, 2006. Print. Studies in Feminist Philosophy.

Anderson, Benedict. Under Three Flags: Anarchism and the Anti-colonial Imagination. London: Verso, 2005. Print.

Anzaldúa, Gloria. Borderlands/La Frontera: The New Mestiza. San Francisco: Aunt Lute, 1999. Print.

Barton, David, and Mary Hamilton. Local Literacies: Reading and Writing in One Community. London:

Routledge, 1998. Print.

Bourdieu, Pierre, and Loïc JD Wacquant. An Invitation to Reflexive Sociology. Chicago: U of Chicago P, 1992.

Print.

Broyles-González, Yolanda. El Teatro Campesino: Theater in the Chicano Movement. Austin: U of Texas P, 1994. Print.

Campano, Gerald. Immigrant Students and Literacy: Reading, Writing, and Remembering. New York: Teachers College P, 2007. Print. Practitioner Inquiry Series.

Campano, Gerald, and María Paula Ghiso. "Immigrant Students as Cosmopolitan Intellectuals." Handbook on Research on Children's and Young Adult Literature. Ed. Shelby A. Wolf, Karen Coats, Patricia Enciso, and Christine A. Jenkins. New York: Routledge, 2011. 164-176. Print.

Campano, Gerald, María Paula Ghiso, Mary Yee, and Alicia Pantoja. “Toward Community Research and Coalitional Literacy Practices for Educational Justice.” Language Arts 90.5 (2013): 314-326. Print.

Cochran-Smith, Marilyn, and Susan L. Lytle. Inquiry as Stance: Practitioner Research in the Next Generation.

New York: Teachers College P, 2009. Print.

Fricker, Miranda. Epistemic Injustice: Power and the Ethics of Knowing. Oxford: Oxford UP, 2007. Print.

Graff, Harvey J. The Literacy Myth: Literacy and Social Structure in the Nineteenth Century City. New York: Academic P, 1979. Print.

Horner, Bruce. 'Ideologies of Literacy, 'Academic Literacies', and Composition Studies." Literacy in

Composition Studies 1.1 (2013): 1-9. Print.

Lugones, María. "Playfulness, 'World'-Travelling, and Loving Perception.” Hypatia 2.2 (1987): 3-19. Print.

Luke, Allan. “Undoing Composition?" Literacy in Composition Studies 1.1 (2013): 70-74. Print.

Mignolo, Walter. The Darker Side of Western Modernity: Global Futures, Decolonial Options. Durham: Duke UP, 2011. Print. Latin America Otherwise Series.

Mohanty, Satya. Literary Theory and the Claims of History: Postmodernism, Objectivity, Multicultural Politics. Ithaca, NY: Cornell UP, 1997. Print.

Moya, Paula. Learning from Experience: Minority Identities, Multicultural Struggles. Berkeley and Los Angeles:

$\mathrm{U}$ of California P, 2002. Print.

Parks, Steve. "Beginnings of a Polemic: Shaking the Borders of a Literate Education." Literacy in Composition Studies 1.1 (2013): 42-44. Print.

Soliday, Mary. "Writing a Self In/Outside School." Literacy in Composition Studies 1.1 (2013): 48-49. Print. Street, Brian V. Literacy in Theory and Practice. Cambridge: Cambridge UP, 1984. Print.

Vieira, Kate. "On the Social Consequences of Literacy." Literacy in Composition Studies 1.1 (2013): 26-32.

Print. 